Hall, R. P. \& Friend, C. R. L. 1979: Structural evolution of the Archean rocks in Ivisârtoq and the neighbouring inner Godthåbsfjord region, southern West Greenland. Geology 7, 311-315.

Kalsbeek, F. \& Myers, J. S. 1973: The geology of the Fiskenæsset region. Rapp. Grønlands geol. Unders. 51, 5-18.

McGregor, V. R., Bridgwater, D. \& Nutman, A. P. 1983: The Qârusuk acid dykes: post-Nûk, pre-Qôrqut magmatism in the Godthåb region, southern West Greenland. Rapp. Grønlands geol. Unders. 112, 101-112.

Nesbitt, R. W. \& Sun, S. S. 1976: Geochemistry of Archaean spinifex-textured peridotites and magnesian and low magnesian tholeiites. Earth planet. Sci. Lett. 31, 433-454.

Nisbet, E. G. 1981: The tectonic setting and petrogenesis of komatiites. In Arndt, N. T. \& Nisbet, E. G. (edit.) Komatiites. 526 pp. London: Allen \& Unwin.

Nutman, A. P. 1982: Investigations on amphibolite facies orthogneisses, amphibolites and leucogabbros on Akugdlerssuaq, inner Godthåbsfjord. Rapp. Grønlands geol. Unders. 110, 72-77.

Nutman, A. P. \& Bridgwater, D. 1983: Deposition of Malene supracrustal rocks on an Amîtsoq basement in outer Ameralik, southern West Greenland. Rapp. Grønlands geol. Unders. 112, 43-51.

Pearce, J. A. \& Norry, M. J. 1979: Petrogenetic implications of Ti, Zr, Y and Nb variations in volcanic rocks. Contrib. Mineral. Petrol. 69, 33-47.

Sun, S. S. \& Nesbitt, R. W. 1978: Petrogenesis of Archaean ultrabasic and basic volcanics: evidence from rare earth elements. Contrib. Mineral. Petrol. 65, 301-325.

Weaver, B. L., Tarney, J. \& Windley, B. F. 1981: Geochemistry and petrogenesis of the Fiskenæsset anorthosite complex, southern West Greenland: nature of the parent magma. Geochim. cosmochim. Acta. 45, 711-725.

Wells, P. R. A. 1979: Chemical and thermal evolution of Archaean sialic crust, southern West Greenland. J. Petrol. 20, 187-226.

A.P.N., Memorial University of Newfoundland, St. John's, Newfoundland, Canada.

\title{
Geological mapping and mineral exploration in the Motzfeldt Centre of the Igaliko nepheline syenite complex, South Greenland
}

\author{
Tapani Tukiainen
}

The mineral occurrences of the Motzfeldt Centre, discovered by the South Greenland regional uranium exploration programme (Armour-Brown et al., 1984, Tukiainen et al., 1984), are now being explored for their $\mathrm{Nb}$ and Ta potential under a project financed by the EEC's Resources and Raw Materials Programme and The Geological Survey of Greenland. Accompanying the mineral exploration several other investigations are being carried out, and there is a close co-operation between the various groups working in the area.

The 1984 field activities comprised geological mapping, geochemical and geophysical investigations, and mineral exploration. The field activities were supported by GGU's facilities at Narssarssuaq where Jørgen Lau acted as base camp manager. A Jet Ranger helicopter, chartered on an ad hoc basis from the Ice Reconnaissance Centre at Narssarssuaq, was used for camp moves, geological reconnaissance and servicing of the field teams. De- 
spite the bad weather conditions which prevailed for most of the season the main objectives of the field work were achieved.

\section{Geological mapping}

A group led by C.H. Emeleus (University of Durham) concentrated on two topics: (1) geological mapping of the Motzfeldt Centre and, (2) mapping and sampling of the Gardar dykes in the region (Pearce \& Emeleus, this report).

The geological mapping of the Motzfeldt Centre initiated in 1982 (Tukiainen et al., 1984) was completed. The main objectives of the seasons mapping were to study the structure and distribution of the syenite units in the western and southern parts of the centre and to correlate these with the syenite units established during the mapping in 1982 . On the whole, the field work confirmed the classification and relations of the syenite units which were established in 1982 and extended these to the south and south-west part of the centre (Bradshaw, this report). The geological map in fig. 19 is the preliminary compilation of the mapping results of the 1982 and 1984 field seasons.

The seasons work gave a more detailed picture of the nature and distribution of the Gardar supracrustal rocks in the Motzfeldt area (Larsen \& Tukiainen, this report).

A lithogeochemical sampling programme was carried out by L. Melchior Larsen. About 270 representative samples of the various syenite units of the Motzfeldt Centre were collected for future chemical investigations. She worked in close co-operation with the Durham group and complemented the mapping programme.

\section{Geophysics}

A group led by L. Thorning made a combined magnetic and VLF survey in north-east Motzfeldt Centre (Thorning \& Boserup, this report). This reconnaissance survey was intended to verify and locate the continuation of the sulphide-bearing fault zones, discovered in 1980 (Armour-Brown et al., 1981), into the poorly exposed basement rocks. The survey confirmed the presence of conductors in some of the fault zones which cut the basement rocks in north-east Motzfeldt Centre. The preliminary interpretation of the survey data indicates that the conductors extend to at least 50-60 $\mathrm{m}$ in depth. The field evidence indicates that the conductors are due to the sulphide mineralisation.

\section{Mineral exploration programme}

A group led by $\mathrm{T}$. Tukiainen carried out detailed mapping and sampling in selected localities in the north and east part of the centre. This was done in collaboration with a team led by G. Morteani (Technical University of Munich).

The objectives of the field work were to measure profiles across the various lithologies of the mineralised syenite and to obtain a representative collection of samples for the laboratory investigations in order to clarify the distribution of $\mathrm{Nb}$, Ta and related elements, as well as to outline zones of economically significant $\mathrm{Nb}$-Ta enrichment.

The field work confirmed the overall distribution and characteristics of the metasomatic alteration and associated mineralisation as found by Tukiainen et al. (1984) and gave a more 


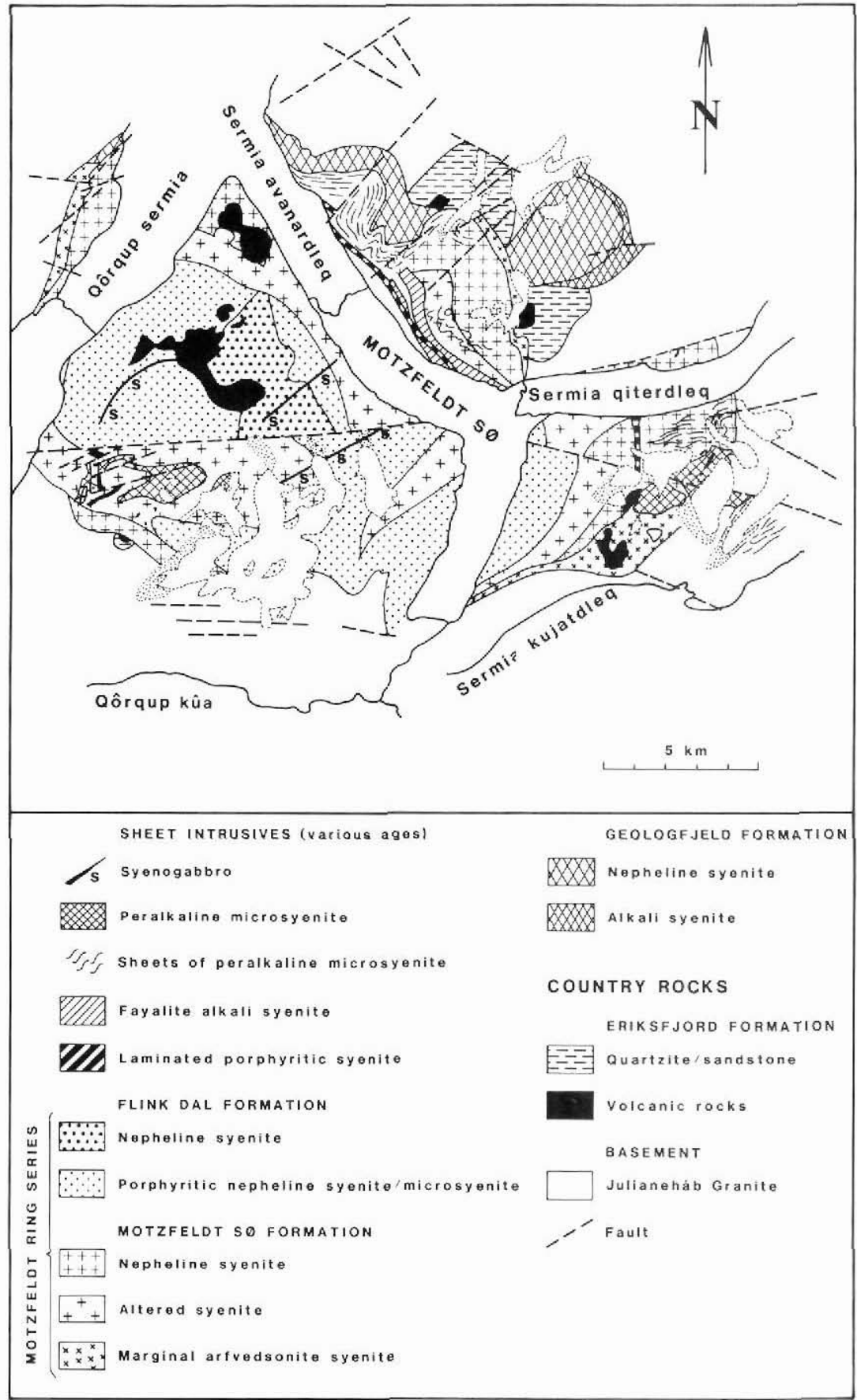

Fig. 19. Geological sketch map of the Motzfeldt Centre. The map is a preliminary compilation of the results of the 1982 and 1984 field seasons. 
detailed picture of the relations of the rock types and the mineralisation/alteration processes.

\section{Peralkaline microsyenite}

The sequence of peralkaline microsyenite sheets in north-east Motzfeldt Centre provides a complete section through this rock unit. Disregarding screens of older syenite, this microsyenite sequence, which has a maximum thickness of about $700 \mathrm{~m}$, consists of two main rock types, microsyenite and pegmatite. The pegmatite, which is often rich in eudialyte, occurs both as concordant layers and as irregular networks in the microsyenite, locally even brecciating it. Pegmatite is most abundant at the higher levels of the sheet sequence. Mineralisation and alteration have affected the uppermost part of the sequence where the intensity of the mineralisation and alteration increases upwards. The thickness of the mineralised section increases from some tens of metres in the north to at least $200 \mathrm{~m}$ in the south. The screens of older syenite in the altered microsyenite are as a rule fresh or only weakly affected by the alteration which indicates that the emplacement of the microsyenite and the alteration/mineralisation were contemporaneous.

In south-east Motzfeldt Centre only the topmost part of the microsyenite sequence could be studied. In contrast to the microsyenite of north-east Motzfeldt Centre the microsyenite here contains only insignificant amounts of pegmatite. The sheets are thoroughly affected by the alteration and mineralisation, and fresh, unmineralised varieties of the microsyenite suite were not found. The sheets attain considerable dimensions, both laterally and vertically. The thickest sheet has a thickness of more than $200 \mathrm{~m}$.

\section{Altered syenite of the Motzfeldt Sø Formation}

The largest pyrochlore mineralisation found so far in the Motzfeldt area was located on the northern side of Sermia qiterdleq, south of the Flinks Dal fault. The locality was investigated in a c. $2 \mathrm{~km}$ long profile along the foot of a cliff about $1200 \mathrm{~m}$ high cliff. The profile is situated below a major radiometric anomaly. The easternmost $c .500 \mathrm{~m}$ wide zone of the altered syenite bordering the basement granite is enriched with disseminated pyrochlore. A rock sample taken from this zone in 1980 contains 0.7 per cent $\mathrm{Nb}$. The mineralisation is also found further east, although it is more diffuse, it is in a $c .600 \mathrm{~m}$ wide contact zone between the altered syenite and the basement granite. The contact zone consists of fenitised basement granite xenoliths in a matrix of hybrid syenite and pegmatite.

\section{Sulphide mineralisation}

Some of the vertical or steep faults dissecting the syenite units of the centre are enriched in sulphides, mainly pyrite with minor sphalerite, galena, chalcopyrite and molybdenite. The mineralisation in the NE-SW trending vertical faults immediately south of the Geologfjeld syenite in north east Motzfeldt Centre was discovered in 1980 (Armour-Brown et al., 1981). One of the sulphide bearing-zones here is at least $5 \mathrm{~m}$ wide but the dimensions of the zones could not be measured because they are obscured by intense weathering and abundant 
scree. The geophysical survey (Thorning \& Boserup, this report) indicates that these sulphide-enriched fault zones extend into the basement rocks. Scattered pyrite-rich blocks were found in the area of the basement rocks. Furthermore, the basement granite adjacent to the mineralised faults is altered and contains sporadic pyrite and galena.

The northernmost E-W trending steep fault in south-east Motzfeldt Centre, on a steep cliff face south of Sermia qiterdleq, contains a sulphide mineralisation which is readily seen from a distance due to its conspicuous ochreous weathering. This sulphide mineralisation could not be visited. During a helicopter reconnaissance in 1982 molybdenite-bearing blocks were found below this fault.

Pyrite is the most common sulphide found so far in the mineralised fault zones. The identification of other sulphides on the outcrops of the intensively weathered, metasomatically altered syenites is difficult, and consequently their abundance and economic significance are still to be investigated.

Acknowledgements. The field work was supported by the European Economic Community through contract number MSM-118-DK(AD). The author wishes to thank J. Lau for his invaluable work as base camp manager in Narssarssuaq and the members of the individual field groups for their contributions to the field work and enjoyable co-operation in the field.

\title{
References
}

Armour-Brown, A., Tukiainen, T. \& Wallin, B. 1981: Uranium districts in South Greenland. Rapp.Grønlands geol. Unders. 105, 51-55.

Armour-Brown, A., Tukiainen, T., Nyegaard, P., Wallin, B. 1984: The South Greenland regional uranium exploration programme. Final report of progress 1980-1983. Unpubl. intern. GGU rep., 107 pp.

Tukiainen, T., Bradshaw, C. \& Emeleus, C. H. 1984: Geological and radiometric mapping of the Motzfeldt Centre of the Igaliko Complex, South Greenland. Rapp. Grønlands geol. Unders. 120, 78-83.

\section{Geological investigations of the Igaliko dyke swarm, South Greenland}

\author{
N. J. G. Pearce and C. Henry Emeleus
}

Field work in 1984 in the Motzfeldt area included an investigation of the Gardar dyke swarm in this area. The dyke swarm was examined at the following places in or near the Igaliko Complex: north of Motzfeldt S $\varnothing$, north of Gieseckes Dal, Igaliko, Flinks Dal, Mellemlandet, in Østfjordsdal (north-west side), and west of Narssarssuaq river.

Except at $\emptyset$ stfjordsdal, the dykes resemble assemblages found elsewhere in the TugtutôqIlímaussaq-Igaliko swarm. Porphyritic and non-porphyritic trachytes and phonolites (the latter less common), basalts and dolerites, lamprophyres, big feldspar dolerites and carbo- 